\title{
$17: 76623557-76705827$
}

National Cancer Institute

\section{Source}

National Cancer Institute. 17: 76623557-76705827. NCI Thesaurus. Code C41746.

Physical location of BAIAP2_Gene 